\title{
Variation in parental investment and relative clutch mass of the spiny-tail iguana, Ctenosaura pectinata (Squamata: Iguanidae) in central México
}

\section{Variación en la inversión parental y masa relativa de la nidada en la iguana de cola espinosa Ctenosaura pectinata (Squamata: Iguanidae) en el centro de México}

\author{
Rubén Castro-Franco $^{1 *}$, María Guadalupe Bustos-Zagal ${ }^{1}$ and Fausto R. Méndez-De la Cruz ${ }^{2}$ \\ ${ }^{l}$ Departamento de Biología Animal, Centro de Investigaciones Biológicas, Universidad Autónoma del Estado de Morelos, Av. Universidad 1001, \\ Chamilpa 62209, Cuernavaca, Morelos, México. \\ ${ }^{2}$ Laboratorio de Herpetología, Departamento de Zoologia, Instituto de Biología, Universidad Nacional Autónoma de México. Apartado postal 70-153, \\ 04510 México D.F., México. \\ *Correspondent: castro@uaem.mx
}

\begin{abstract}
We measured the length, width, volume, and weight of 871 freshly laid eggs of 28 clutches of Ctenosaura pectinata. The iguanas were obtained from a tropical dry forest area in central Mexico. The relative clutch mass was related positively to the average egg weight but not to average egg volume. Unlike what usually occurs in lizards, where the body length strongly predicts egg production, in C. pectinata clutch size and egg size were not correlated with female weight or snout-vent length. Observed differences revealed variation in the weight-size of the egg within an individual clutch. Therefore, there is not an optimization of the egg in the studied population of Ctenosaura, as usually occurs in small lizards. This variation associated with reproduction takes place in the middle of the dry season, and may be interpreted as an adaptation to facilitate the adjustment of different phenotypes in environments with extreme drought.

Key words: Ctenosaura pectinata, Mexico, parental investment, clutch variation.

Resumen. Medimos la longitud, amplitud, volumen, y peso de 871 huevos recién puestos de 28 nidadas de Ctenosaura pectinata. Las iguanas fueron obtenidas en un área de bosque tropical seco en el centro de México. La masa relativa de la nidada estuvo relacionada positivamente con el peso promedio de los huevos pero no con el volumen promedio del huevo. A diferencia de lo que ocurre usualmente en lagartijas, donde la longitud del cuerpo determina la producción de huevos, en C. pectinata el tamaño de la puesta y el tamaño del huevo no se correlacionan con el peso y tamaño de las hembras. Las diferencias observadas revelan variación en el tamaño y peso de los huevos dentro de las puestas individuales. En consecuencia, no hay una optimización del huevo en la población estudiada de Ctenosaura, como usualmente ocurre en lagartijas de tamaño pequeño. Esta variación asociada con la reproducción tiene lugar a mitad de la estación seca, y puede ser interpretada como una adaptación para facilitar el ajuste de diferentes fenotipos en ambientes con sequía extrema.
\end{abstract}

Palabras clave. Ctenosaura pectinata, México, inversión parental, variación en la puesta.

\section{Introduction}

Reproductive strategies in reptiles involve variation in clutch size, incubation time, and intra-clutch variation in egg weight and size (Sinervo and Licht, 1990; Craig et al., 1990, Rodriguez-Romero et al., 2004; Wilkinson and Gibbons, 2005). These patterns of variation usually have been considered to be promoted by environmental factors. Within lizards, patterns of variation in clutch and egg

Recibido: 23 febrero 2009; aceptado: 25 junio 2010 size (Van Marken and Albers, 1993; Rand, 1994; Ji and Brana, 2000; Shanbhag et al., 2000) have been attributed to variation in climate conditions among high and low elevations/latitudes, and their effects on the environment temperature and humidity variations (Fitch, 1985). Within the same population, variation among years is considered to result from responses to food availability, predation intensity, female size, and other local environmental factors (Vitt and Price, 1982; De Marco, 1989; Abell, 1999). Previous studies have shown that in lizards, clutch size variation is related to female size or weight in both oviparous and viviparous species and the pattern is 
consistent in semelparous and early-maturing iteroparous species (Rodríguez-Romero et al., 2004; Du et al., 2005; Herrman and Herrman, 2005). However, this pattern is less common and not consistent within iteroparous, long-lived and late-maturing lizard species (Shanbhag et al., 2000). According to previous studies among lizards, Iguana iguana show unusually large clutches and these are not related to female size (Van Marker and Albers, 1993). Moreover, notable egg size variation within clutches was recorded (Rand, 1994; Alvarado et al., 1995). Variation in clutch size in lizards can also result from the effect of proximate environmental factors and from changes in the physiological condition of females (Dunham et al., 1989). This lack of a generalized pattern is not only seen in these long-lived lizards, but also in some turtles (i.e., Gopherus and Kinosternon), lizards (i.e. Amphibolurus muricatus Warner et al., 2008) and snakes (Vipera aspis, Bonnet et al., 2001) where variation in clutch size was not explained by mother's size or weight (Andrew and Aguirre, 1995; Wilkinson and Gibbons, 2005), and was attributed to such proximate factors as resource availability and the metabolic rate of the mother. The mother may present differences in metabolic rate during follicle recruitment and vitellogenesis (Warner et al., 2008; Bonnet et al., 2001), which can last from fall through spring.

The present paper addresses the study of variation in clutch size and relative clutch mass in the spiny-tail iguana (Ctenosaura pectinata). Our results support the fact that iteroparity in large and long-lived lizards is commonly associated with 1) a pattern in which clutch-size variation is related to weight of females instead of snout-vent length, and 2) significant within-clutch variation in the size of eggs depending on the weight of females.

\section{Material and methods}

Subjects came from a tropical dry forest with a subhumid climate in central México, Sierra de Huautla, Morelos (18 $24^{\prime} \mathrm{N}$ and $99^{\circ} 03^{\prime} \mathrm{W}$; $930 \mathrm{~m}$ elevation). The most common species are Ipomoea intrapilosa, Pithecelloboium dulce, Acacia acatlensis, Plumeria rubra, Acacia cymbispina and Ceiva parvifolia. The driest months are January $(10.8 \mathrm{~mm})$, March $(0.0 \mathrm{~mm})$ and April $(6.3 \mathrm{~mm})$, and the hottest months are April to $26.2^{\circ} \mathrm{C}$ and May with $26.3^{\circ} \mathrm{C}$. The average annual temperature in this area is $24.9^{\circ} \mathrm{C}(23.6-26.3 \pm 0.89)$.

Gravid females $(n=28)$ were collected during April in different years: $1995 n=7,2003 n=14$, and $2005 n=7$. Each female was kept and watched during the last week of gravidity in a plastic box $(60 \times 40 \times 15 \mathrm{~cm})$ with vermiculite (horticulture grade Terra/Lite), moisture between $15-20$
$\%$, dim light, and temperature between $28-30^{\circ} \mathrm{C}$. Freshlylaid eggs were measured and weighed and females were returned to their natural habitat.

Data recorded from each female were snout-vent length (SVL), total weight (TW), and clutch size. All the eggs from each clutch were measured with digital calipers $(0.01 \mathrm{~mm})$ and weighed on a digital balance $(0.1 \mathrm{~g})$. Clutch size was considered as the total count of eggs produced by each female. Volume of each egg was obtained by the equation for an ellipsoid, $\mathrm{V}=4 / 3 \pi(1 / 2 L)(1 / 2 W)^{2}$, where $L$ is the longest diameter and $W$ is the shortest diameter. Total volume and total weight of the clutch were obtained by summing these individual measurements for all freshlylaid eggs produced by each female. Relative clutch mass was calculated by the egg weight/ female mass quotient after having laid the eggs (Cuellar, 1984; RodríguezRomero et al., 2002). The variation in relative clutch mass (RCM) and clutch size was calculated among females, whereas that of egg size and egg volume was calculated within the individual clutches. We used the coefficient of variation $(\mathrm{CV}=$ standard deviation/mean $\times 100 \%)$ as a measure of variation considering $(\mathrm{CV}<5 \%$ as invariant, and $>5.1 \%$ as variable). To evaluate whether the weight of females might affect their reproductive characteristics, both the female weight and the residuals of the regression of female weight against SVL (which is a measure of female body nutritional condition) were used as the independent variables in separate regressions with number of eggs and average weight of the eggs as dependent variables. Additionally, to analyze whether variation in the volume and weight of eggs was explained by the traits of the females, SVL and weight of females after oviposition were compared by regression analyses with $\mathrm{CV}$ of volume and weight of freshly-laid eggs.

To analyze whether the amount of precipitation might influence reproductive characteristics like clutch size, egg volume, and egg weight, a regression analysis was applied considering the amount of rainfall (May to September) from the previous year. Considering that reproductive season analyzed as vitellogenesis and mating occur from January to February. All analyses were conducted in Statistica 6.0 (StatSoft).

\section{Results}

A total of 871 eggs were collected from 28 females with an average size of $289.3 \mathrm{~mm} \mathrm{SVL}( \pm 23.5$, range of 240.0-340.0) across the 3 years of the study. Average clutch size was 31.1 eggs $( \pm 11.6$, range of $12.0-52.0, \mathrm{CV}$ $=37.5 \%)$, with a mean egg volume of $7.39 \mathrm{~cm}^{3}( \pm 2.07$ range of $3.3-17.27, \mathrm{CV}=28.07 \%$ ), maximum diameter 
of $30.9 \mathrm{~mm}$ ( \pm 2.2 , range of $18.0-40.5, \mathrm{CV}=7.3 \%)$, minimum diameter of $21.16 \mathrm{~mm}( \pm 2.4$, range of 16.2 - 32.0, CV $=11.3 \%)$, and a mean weight of $7.46 \mathrm{~g}( \pm$ 1.7 , range of $5.1-15.6, \mathrm{CV}=23.48 \%$ ). Average relative clutch mass was $0.40( \pm 0.09$, range of $0.23-0.56, \mathrm{CV}=$ $22.5 \%)$, and was related to average egg weight $(r=0.411$, $\left.R^{2}=0.168, \mathrm{~F}_{1,26}=5.07, \mathrm{P}=0.033\right)$, and not related to the average egg volume $\left(r=0.293, R^{2}=0.085, \mathrm{~F}_{1,26}=2.43, \mathrm{P}\right.$ $=0.13)$. A positive relationship between clutch size and average egg weight was found $\left(r=0.408, R^{2}=0.16, \mathrm{~F}_{1,26}\right.$ $=5.0, \mathrm{P}=0.034)$. In contrast, clutch size was not related to maximum egg diameter $\left(r=-0.025, R^{2}=0.0006, \mathrm{~F}_{1.26}\right.$ $=0.01, P=0.899)$ nor to average egg volume $(r=0.040$, $\left.R^{2}=0.0016, \mathrm{~F}_{1.26}=0.04, \mathrm{P}=0.836\right)$. Average egg length was significantly related to female weight (Table 1). Clutch size was not correlated with robustness of female (body condition) (Fig. 1A). Average weight of eggs was not related to female robustness (Fig. 1B). Neither clutch nor egg characteristics were explained by the SVL females

Table 1. Regression analysis $(r)$ between reproductive traits and female weight and length of the spiny-tail iguana, Ctenosaura pectinata $. \mathrm{ns}=$ non significant. Clutch size and Relative clutch mass $n=28$; Average egg size, Average egg volume and Average egg weight $n=871$ eggs

\begin{tabular}{lccccc}
\hline & $\begin{array}{c}\text { Clutch } \\
\text { size }\end{array}$ & $\begin{array}{c}\text { Average } \\
\text { egg } \\
\text { size }\end{array}$ & $\begin{array}{c}\text { Average } \\
\text { egg } \\
\text { volume }\end{array}$ & $\begin{array}{c}\text { Average } \\
\text { egg } \\
\text { weight }\end{array}$ & $\begin{array}{c}\text { Relative } \\
\text { clutch } \\
\text { mass }\end{array}$ \\
\hline $\begin{array}{l}\text { Weight of } \\
\text { females } \\
(n=28)\end{array}$ & $0.460^{\text {ns }}$ & $0.450^{\text {ns }}$ & $0.223^{\text {ns }}$ & $0.125^{\text {ns }}$ & $0.364^{\mathrm{ns}}$ \\
$\begin{array}{l}\text { Snout-vent } \\
\text { length } \\
\text { females } \\
(n=28)\end{array}$ & $0.372^{\text {ns }}$ & $0.332^{\text {ns }}$ & $0.140^{\text {ns }}$ & $0.183^{\text {ns }}$ & $0.080^{\text {ns }}$ \\
\hline
\end{tabular}

(Table 1), Clutch size $\left(r=0.250, R^{2}=0.062, \mathrm{~F}_{1,26}=1.68\right.$, $P=0.206)$, average volume $\left(r=0.161, R^{2}=0.026, \mathrm{~F}_{1.26}=\right.$ $0.66, \mathrm{P}=0.421)$ and weight of eggs $\left(r=0.142, R^{2}=0.020\right.$, $\left.\mathrm{F}_{1,26}=0.51, \mathrm{P}=0.478\right)$ were not affected by the rainfall amount of the year previous to reproduction.

The regression analyses showed that the coefficient of variation (CV) of weight of freshly laid eggs was neither related to female SVL $\left(r=0.163, R^{2}=0.026, \mathrm{~F}_{1,26}=0.71\right.$,

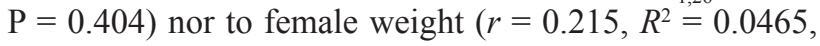
$\left.\mathrm{F}_{1,26}=1.26, \mathrm{P}=0.270\right)$.

Females of Ctenosaura pectinata laid clutches with a wide variation in egg size and weight (Fig. 2). $75 \%$ of clutches showed an average $\mathrm{CV}$ of $9.47( \pm 3.90$, range of 5.3-21.0), whereas only $25 \%$ produced more evenly
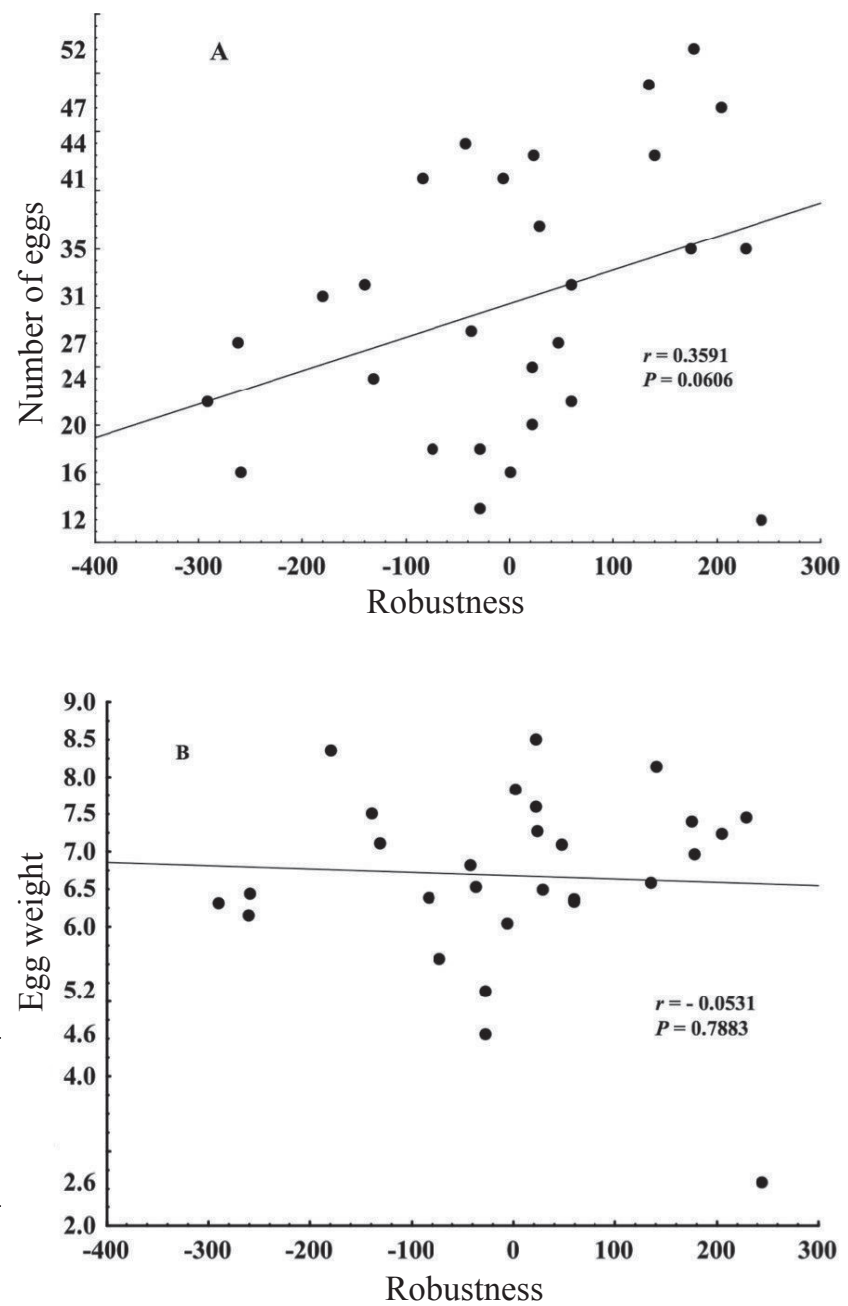

Figure 1. Relationship between the residuals from female weight against female snout-vent length (robustness a measure of body nutritional condition) and (A), the number of eggs produced per female, and (B), the weight of the eggs.

sized eggs $(\mathrm{CV}<5 \%)$. Within-clutch variation of egg volume (measured as $\mathrm{CV}$ ) was neither related to SVL $\left(r=0.239, R^{2}=0.488, \mathrm{~F}_{1,26}=1.57, \mathrm{P}=0.219\right)$, nor to female weight $\left(r=0.302, R^{2}=0.549, \mathrm{~F}_{1,26}=2.61, \mathrm{P}=0.117\right)$.

\section{Discussion}

With some exceptions, in general, variation in the clutch size of lizards is explained by a positive relationship of clutch size and female snout-vent length (Fitch, 1985). In addition, the egg has been considered to be under a high evolutionary pressure to be relatively invariant in size (Shine and Greer, 1991; Shine, 2005). In Ctenosaura pectinata clutch size was not found to be related to the 

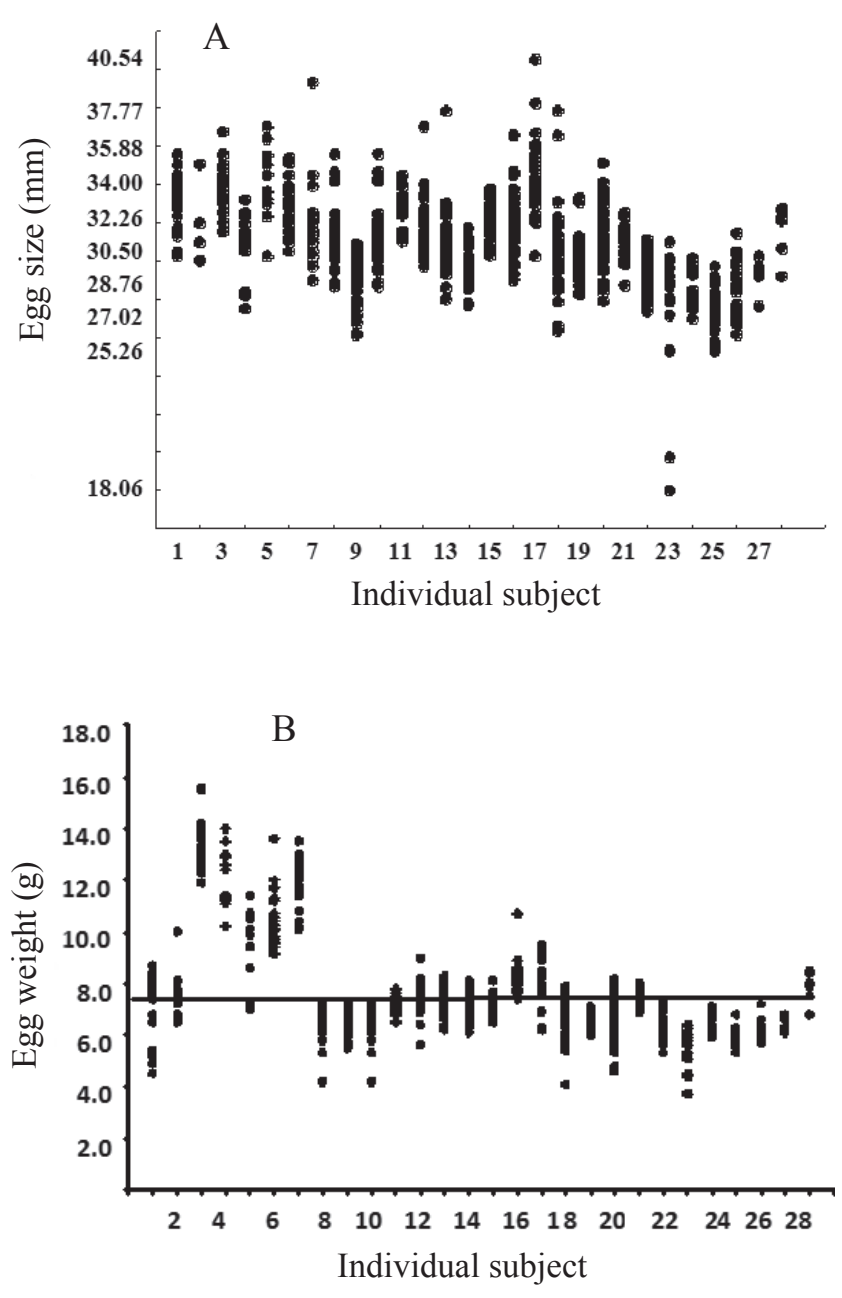

Figure 2. Within clutch variation in egg size (A), and weight (B) of freshly-laid eggs of Ctenosaura pectinata. The horizontal lines show average size $(30.92 \mathrm{~mm})$ and weight (7.72) of eggs for all females.

weight of females, nor to snout-vent length. The substantial variation observed in the clutch size among females of Ctenosaura pectinata is similar to that in Iguana iguana, Ctenosaura similis, several species of Cyclura, Sauromalus, and Xenosaurus (Van Marker and Albers, 1993; Zamora-Abrego et al., 2007).

In turtles the nutritional condition of females determined egg size and was associated with number and position of follicles (Wilkinson and Gibbons, 2005). Egg size also varied among the first, second, and third clutches due to decrease in resource availability. In C. pectinata, we found only 1 clutch per year, but we observed considerable variation in clutch size (12 -52 eggs) and in the sizes of eggs within a clutch (from 18.06 to $30.92 \mathrm{~mm}$ in length).
According to Wilkinson and Gibbons (2005) smaller eggs may correspond to those that were incorporated late to the clutch, when the availability of resources from the mother was depleted. The utilization of both endogenous energy stores "capital", and recently acquired food to fuel reproduction "income", has been previously observed in agamid lizards (Warner et al., 2008). Vitellogenic follicles of different size were observed in the ovary of $C$. pectinata with platelets of 3 different sizes and various kinds of morphology (Uribe at al., 1996).

Considerable variation in clutch size of $C$. pectinata has been observed previously in lizards (Uller et al., 2008) and other large reptiles, such as tortoises and crocodiles (Fitch, 1985; Casas-Andreu, 2003; Roosenburg and Dennis, 2005). All these taxa are late-maturing, long-lived, and produce variable large clutches.

Relative clutch mass is considered to be influenced by foraging mode and predator escape tactics (Vitt and Price, 1982), although it does not appear to be consistent. Species with the widely foraging mode usually show low relative reproductive outputs, whereas sit-and-wait species show higher values (Vitt et al., 2003). Therefore, C. pectinata may be considered a sit and wait forager (Vitt and Congdon, 1978) considering its feeding habits with adaptations for herbivory (Iverson, 1982) and that it shows a high relative reproductive output of 0.40 with a high $\mathrm{CV}=24.68$.

Relative clutch mass and its variability are directly related in lizards. Several members of the genera Anolis, Tropidurus, Niveoscincus, Scleoporus, Calotes, and Tiliqua exhibit low mean RCM values as well as low variability in this trait (less than $10 \%$, Feria et al., 2001; Chapple et al., 2002; Ji et al., 2002; Milne and Bull, 2002; Wiederhecker et al., 2002; Rodríguez-Romero et al., 2004; Vitt and Zani, 2005). Lizards with moderate reproductive output exhibit moderate variation in RCM index (11.0-17.0\%), for example Oedura lesuerii, Aspidoscelis lineatissima, and S. aeneus (Doughty, 1997; Ramírez-Bautista et al., 2000; Rodríguez-Romero et al., 2002). Finally, Xenosaurid and Iguanid lizards, Australian skinks, Ctenophorus fioni and S. bicantalis (Johnston, 1999; Rodríguez-Romero et al., 2002, Knapp and Shedd, 2003; Zamora-Abrego et. al., 2007) invest the highest values of RCM and show the highest variation (from 20.0 to $42.0 \%$ ).

Lizards that show the highest values are not phylogenetically close, but all of them occur in extreme environments (high altitude or desert conditions), which suggests that high values of RCM and its variability might be selected in severe environments, as an adaptive mechanism.

The environment that Ctenosaura pectinata inhabits may be considered a harsh environment because of the dry conditions (when the laying period occurs) that last 8 
months (from October to May). The RCM and the variation of it in $C$. pectinata are relatively high and may be as a consequence of the environment, specifically during the reproductive season.

Within-clutch variation in Ctenosaura pectinata could have been selected to facilitate fitness of different phenotypes in changing and unpredictable conditions. Long-lived iteroparous species (i.e., iguanas) have more chances to test different reproductive outputs and phenotypes during longer periods of time. This variability has been interpreted in terms of a plasticity model, considering that the same genetic load may respond to differences in environmental opportunities (Wilkinson and Gibbons, 2005).

Low values of relative clutch mass are associated with low variation in the size and weight of eggs. Low variation implies either an optimization of the individual egg or an evolutionary constraint (Harvey and Pagel, 1991). In contrast, high values of RCM are related with high variation in the size and weight of eggs. In general, large species are associated with long life spans, high values of $\mathrm{RCM}$, and considerable variation in egg size as a strategy to produce variation in their progeny. Differences in the size and weight of the progeny within the same clutch, as in turtles and iguanas, may be interpreted in terms of the highest chances of hatchling survivorship, while facing extreme or unpredictable environments (Roff, 1982; Charnov, 2002). High values of annual juvenile survival (0.47- 0.81) were observed previously in several species of turtles (Pike, et. al., 2008). We consider that Ctenosaura pectinata represents a good model to test this theory in iguanas, considering that its eggs show extensive variation in size and weight, in opposition to species that lay eggs optimized in size and weight, i.e., with restricted variation.

\section{Acknowledgments}

This study was supported by research grants from the Programa de Mejoramiento de Profesores (PROMEP) and the PROMEP-UAEMOR/08/ of the Secretaría de Educación Pública - México, the Centro de Investigaciones Biológicas - Universidad Autónoma del Estado de Morelos and the Programa de Posgrado en Ciencias Biológicas Universidad Nacional Autónoma de México. The permit for collecting lizards was provided by SEMARNAT - México (No. SGPA/DGVS/03490). J. Zúñiga-Vega, Maricela Villagrán Santa Cruz from UNAM, and Stanley F. Fox from Oklahoma State University, provided helpful comments that considerably improved the manuscript.

\section{Literature cited}

Abell, A. J. 1999. Variation in clutch size and offspring size relative to environmental conditions in the lizard Sceloporus virgatus. Journal of Herpetology 33:173-180.

Alvarado, J., L. Ibarra, I. Suazo, G. Rodríguez and R. Zamora. 1995. Reproductive characteristics of a green iguana (Iguana iguana) population of the west coast of Mexico. Southwestern Naturalist 40:234-237.

Andrew, A. G. and L. G. Aguirre. 1995. Natural and life history of the Bolson Tortoise, Gopherus flavomarginatus. Publicaciones de la Sociedad Herpetologica Mexicana 2:1-5.

Bonnet, X., G. Naulleau, R. Shine and O. Lourdais. 2001. Shortterm versus long-term effects of food intake on reproductive output in a viviparoussnake, Vipera aspis. Oikos 92, 297-308.

Casas-Andreu, G. 2003. Ecología de la anidación de Crocodylus acutus (Reptilia: Crocodylidae) en la desembocadura del río Cuitzmala, Jalisco, México. Acta Zoológica Mexicana (n.s.) 89:111-128.

Chapple, D. G., C. J. McCoull and R. Swain. 2002. Changes in reproductive investment following caudal autotomy in viviparous skink (Niveoscincus metallicus): lipid depletion or energetic diversion?. Journal of Herpetology 36:480-486.

Charnov, E. L. 2002. Reproductive effort, offspring size and benefitcost ratios in the classification of life histories. Evolutionary Ecology Research 4:749-758.

Craig, D., J. and W. G. Whitford. 1994. An experimental study of the phenotypic plasticity in the clutch size of a lizard. Oikos 70:49-56.

Cuellar, O. 1984. Reproduction in a parthenogenetic lizard: with a discussion of the optimal clutch size and a critique of the clutch weight/body weight ratio. American Midland Naturalist 111:242-258.

De Marco, V. G. 1989. Annual variation in the seasonal shift in egg size and clutch size in Sceloporus woodi. Oecologia 80:525-53Doughty, P. 1997. The effects of "fixed" clutch sizes on lizards life-histories reproduction in the Australian velvet gecko, Oedura lesueurii. Journal Herpetology 31:266-272.

Du W., X. Ji, Y. Zhang, X. Xu and R. Shine. 2005. Identifying sources of variation in reproductive and life history traits among five populations of a Chinese lizard (Takydromus septentrionalis, Lacertidae). Biological Journal of the Linnean Society 85:443453.

Dunham, A. E., B. W. Grant and K. L. Overall. 1989. Interfaces between biophysical and physiological ecology and the population ecology of terrestrial vertebrate ectotherms. Physiological Zoology 620:335-355.

Feria, O. M., A. Nieto-Montes de Oca and I. H. Salgado. 2001. Diet and reproductive biology of the viviparous lizard Sceloporus torquatus torquatus (Squamata: Phrynosomatidae). Journal of Herpetology 35:104-112.

Fitch, H. S. 1985. Variation in clutch and litter size in new world 
reptiles. Miscellaneous Publication University of Kansas Museum of Natural History 76:1-75.

Harvey, P. H. and M. D. Pagel. 1991. The comparative method in evolutionary Biology. Oxford Series in Ecology and Evolution, Oxford Univ. Press. 239 p.

Herrman, P. A. and H. W. Herrman. 2005. Egg and clutch characteristics of the mountain chameleon, Chameleo montium, in southwestern Cameroon. Journal of Herpetology 39:154157.

Iverson, J. B. 1982. Adaptations to herbivory in iguanine lizards. In Iguanas of the World their Behaviour, Ecology, and Conservation, G. M. Burghardt and A. S. Rand (eds.). Noyes Publicatons, New Jersey, USA. 471 p.

Ji, X. A. and F. Brana. 2000. Among clutch variation in reproductive output and egg size in the wall Lizard (Podarcis muralis) from a lowland population of northern Spain. Journal of Herpetology 34:54-60.

Ji, X., Q. B. Qui and D. C. Hoong. 2002. Sexual dimorphism and female reproductive characteristics in the oriental garden lizard, Calotes versicolor, from Hainan, Southern China. Journal of Herpetology 36:1-8.

Johnston, G. 1999. Reproductive biology of the Peninsula dragon lizard, Ctenophorus fionni. Journal of Herpetology 33:694-698.

Knapp, C. and J. G. Shedd. 2003. Andros iguana (Cyclura cychlura cychlura) and Exuma Islands iguana (C. cychlura figginsi). Iguana Specialist Group Newsletter 6:23-29

Milne, T. and C. M. Bull. 2002. Characteristics of litters and juvenile dispersal in the endangered Australian skink Tiliqua adelaidensis. Journal of Herpetology 36:110-112.

Pike, D. A., L. Pizzatto, B. A. Pike and R. Shine. 2008. Estimating survival rates of uncatchable animals: The myth of high juvenile mortality in reptiles. Ecology 89(3): 607-611.

Ramírez-Bautista, A., C. Balderas-Valdivia and L. J. Vitt. 2000. Reproductive ecology of the whiptail lizard Cnemidophorus lineatissimus (Squamata: Teiidae) in a tropical dry forest. Copeia 2000:712-722.

Rand, A. S. 1994. Clutch size in Iguana iguana in Central Panama. In Vertebrate Ecology and Systematic-a tribute to Henry S. Fitch. R. A. Seigel, E. J. Hunt, L. Knight, L. Malaret and N. L. Zuschlag (eds.). Museum Natural History University Kansas, Lawrence. p.115-122.

Rand, W. L. and G. J. Whitfield. 2005. Patterns of reproductive allocation: clutch and egg size variation in three freshwater turtles. Copeia 2005:868-879.

Rodríguez-Romero, F., F. R. Méndez de la Cruz, R. García-Collazo and M. Villagrán-Santa Cruz. 2002. Comparación del esfuerzo reproductor en dos especies hermanas del género Sceloporus (Sauria:Phrynosomatidae) con diferente modo reproductor. Acta Zoológica Mexicana (n.s.) 85:181-188.

Rodríguez-Romero, F., G. R. Smith, O. Cuellar and F. R. Méndez de la Cruz. 2004. Reproductive traits of a high elevation viviparous lizard Sceloporus bicanthalis (Lacertilia: Phrynosomatidae) from Mexico. Journal of Herpetology 38:438-443.

Roff, D. A. 1982. The evolution of life histories: Theory and analysis. New York, Chapman and Hall. 535 p.

Roosenburg, W. M. and T. Dennis. 2005. Egg component comparisons within and among clutches of the diamondback terrapin, Malaclemys terrapin. Copeia 2005:417-423.

Shanbhag, B. A., R. S. Radder and S. K. Saidapur. 2000. Maternal size determines clutch mass, whereas breeding timing influences clutch and egg size in the tropical lizard, Calotes versicolor (Agamidae). Copeia 2000:1062-1067.

Shine, R. 2005. Life-history evolution in reptiles. Annual Review of Ecology, Evolution, and Systematic 36:23-46.

Shine, R. and A. E. Greer. 1991. Why are clutch sizes more variable in some species than in others?. Evolution 45:1696-1706.

Sinervo, B. and P. Licht. 1990. The evolution of maternal investment in lizards: an experimental and comparative analysis of egg size and its effect on offspring performance. Evolution 44:279-294.

Uller, T. , G. M. While, E. Wapstra, D. A. Warner, B. A. Goodman, L. Schwarzkopf, T. Langkilde, P. Doughty, R. S. Radder, D. H. Rohr, C. M. Bull, R. Shine and M. Olsson. 2009. Evaluation of offspring size-number invariants in 12 species of lizard. Journal Evolutive Biology 22:143-151.

Uribe, A. M. C., G. L. Portales and L. J. Guillete Jr. 1996. Ovarian folliculogenesis in the oviparous Mexican lizard Ctenosaura pectinata. Journal of Morphology 230:99-112.

Van Marker L. W. D. and K. B. Albers. 1993. Reproductive adaptations of the green iguana on a semiarid island. Copeia 1993:790-798.

Vitt, L. J. and H. J. Price. 1982. Ecological and evolutionary determinants of relative clutch mass in lizards. Herpetologica 38:237-255.

Vitt, L. J. and J. D. Congdon. 1978. Body shape, reproductive effort, and relative clutch mass in lizards: resolution of a paradox. American Naturalist 112:595-608.

Vitt, L. J. and P. A Zani. 2005. Ecology and reproduction of Anolis capito in rain forest of southeastern Nicaragua. Journal of Herpetology 39:36-42.

Warner, D. A., X. Bonnet, K. A. Hobson and R. Shine. 2008. Lizards combine stored energy and recently acquired nutrients flexibly to fuel reproduction. Journal of Animal Ecology 77: 1242-1249.

Wiederhecker, H. C., A. C. Pinto and G. R. Colli. 2002. Reproductive ecology of Tropidurus torquatus (Squamata: Tropiduridae) in the high seasonal cerrado Biome of central Brazil. Journal of Herpetology 36:82-91.

Wilkinson, L. R. and J.W. Gibbons. 2005. Patterns of reproductive allocation: clutch and egg size variation in three freshwater turtles. Copeia 2005:868-879.

Zamora-Abrego, J.G., J. J, Zuñiga-Vega and A. Nieto-Montes de Oca. 2007. Variation in reproductive traits within the lizards genus Xenosaurus. Journal of Herpetology 41:630-637. 